\title{
Research Communication \\ Exhaled Nitric Oxide is Decreased by Exposure to the Hyperbaric Oxygen Therapy Environment
}

\author{
Zudin A. Puthucheary, ${ }^{1}$ Jia Liu, ${ }^{1}$ Michael Bennett, ${ }^{2}$ Barbara Trytko, ${ }^{2}$ \\ Sharron Chow, ${ }^{1}$ and Paul S. Thomas ${ }^{1}$ \\ ${ }^{1}$ UNSW and Department of Respiratory Medicine, Faculty of Medicine, Prince of Wales Hospital, Randwick, NSW 2031, Australia \\ ${ }^{2}$ Hyperbaric Unit, Prince of Wales Hospital, Randwick, NSW 2031, Australia
}

Received 30 May 2006; Revised 24 August 2006; Accepted 25 August 2006

\begin{abstract}
Exhaled nitric oxide (eNO) detects airway inflammation. Hyperbaric oxygen therapy (HBOT) is used for tissue hypoxia, but can cause lung damage. We measured eNO following inhalation of oxygen at different tensions and pressures. Methods. Part 1, eNO was measured before and after HBOT. Part 2, normal subjects breathed $40 \%$ oxygen. Results. Baseline eNO levels in patients prior to HBOT exposure were significantly higher than in normal subjects $(P<.05)$. After HBOT, eNO significantly decreased in patients $(15.4 \pm 2.0$ versus $4.4 \pm 0.5 \mathrm{ppb}, P<.001)$, but not in normal subjects, after either $100 \% \mathrm{O}_{2}$ at increased pressure or $40 \%$ oxygen, 1 ATA. In an in vitro study, nitrate/nitrite release decreased after 90 minutes HBOT in airway epithelial (A549) cells. Conclusion. $\mathrm{HBO}$ exposure causes a fall in eNO. Inducible nitric oxide synthase (iNOS) may cause elevated eNO in patients secondary to inflammation, and inhibition of iNOS may be the mechanism of the reduction of eNO seen with HBOT.
\end{abstract}

Copyright ( 2006 Zudin A. Puthucheary et al. This is an open access article distributed under the Creative Commons Attribution License, which permits unrestricted use, distribution, and reproduction in any medium, provided the original work is properly cited.

\section{INTRODUCTION}

Exhaled nitric oxide (eNO) is a marker of airway inflammation [1]. Although NO is produced in the airways by a variety of cells, large amounts may be generated from those involved in the acute and chronic inflammatory responses [2]. NO plays a role in pulmonary host defence mechanisms, and is thought to have both bactericidal and bacteriostatic effects $[3,4]$. Exhaled NO is released by nitric oxide synthases (NOS), including neuronal NOS (nNOS, Type 1), inducible NOS (iNOS, Type 2), and endothelial NOS (ecNOS, Type 3). These NOS isoforms have been demonstrated in the airways of many mammalian species including man $[5,6]$. iNOS is generally not expressed unless the cells have been induced by certain cytokines, however, when stimulated, high concentrations $(\mu \mathrm{M})$ of $\mathrm{NO}$ are produced [7-9]. Thus, an increase in exhaled NO may be due to upregulation of iNOS within epithelial cells in response to proinflammatory cytokines and oxidants $[10,11]$.

In recent years, $\mathrm{eNO}$ has been used as a sensitive marker of asthmatic airway inflammation $[12,13]$. The assay is easy to perform and reproducible with clinically useful sensitivity and specificity [1].

Hyperbaric oxygen therapy (HBOT) is used for the treatment of a number of conditions associated with tissue hy- poxia, including late radiation tissue injury and diabetic foot ulcers. These conditions are associated with hypoxia at the site of disease, and improving oxygenation may assist in the resolution of these lesions. Despite these beneficial effects, HBOT is associated with some undesirable side effects. Hyperoxia has long been associated with tissue damage and the development of lung diseases. The mechanism is not fully understood, but may be attributed to reactive oxygen species (producing oxygen free radicals, ROS) which induce the pulmonary cytochrome P450 enzymes [14-16]. This is supported by animal research into neonatal bronchopulmonary dysplasia, which has shown an arrest in alveolar and capillary development in positive pressure ventilated animals [17]. It has been reported that ventilation with atmospheric hyperoxia in isolated perfused lungs increased NO generation $[18,19]$. Conflicting reports in the literature have been described in studies of humans breathing $100 \% \mathrm{O}_{2}[20,21]$. These changes associated with hyperoxia have been explained by the bonding of oxygen free radicals $\left(\mathrm{O}^{*}\right)$ to extracellular $\mathrm{NO}$ in the body generating peroxynitrite $(\mathrm{ONOO}-)$ which is a strong oxidant and which has been reported to increase iNOS expression [22-25]. However, not all studies are consistent with these findings and hyperbaric oxygenation (HBO) has been shown to decrease NO generation in animal models 
of shock, perhaps via a decrease in the activity of iNOS [26].

This study aimed to measure alterations in eNO following a standard hyperbaric oxygen regime in those with tissue hypoxia and to compare them with normal subjects who were either attendants in the HBO chamber or who breathed supplemental oxygen at sea level. It was hypothesised that hyperoxia could downregulate exhaled nitric oxide. In addition it was hypothesised that the changes in eNO would be reflected in the ability of isolated pulmonary cells to generate nitrite in vitro under similar conditions as experienced by the patients.

\section{METHODS}

\section{Subjects}

Following the ethics committee's approval of the experimental protocol and written informed consent, patients undergoing $\mathrm{HBO}$ at the Prince of Wales Hospital Department of Diving and Hyperbaric Medicine were recruited to the study. All patients were undergoing HBOT for medical indications and no patient was subjected to HBOT purely for the sake of the study. These subjects were asked to complete a questionnaire detailing their medical history, current medications (particularly the use of glucocorticosteroids or nonsteroidal anti-inflammatory agents (NSAIDS)), and specific questions regarding the diagnoses of asthma, chronic obstructive pulmonary disease or other pulmonary diseases, diabetes mellitus, and ischemic heart disease. Smoking history was obtained. Normal subjects were recruited from hospital staff and also completed the same questionnaire.

\section{Exhaled nitric oxide measurements}

The sampling and measurement procedure was as follows: subjects were asked to inhale orally and exhale into a 2-liter gas impermeable bag with a one way valve, generating a positive pressure to close the velum $[27,28]$. If unable to fill this in one breath, a second breath was used. The samples were then analysed within 60 minutes using a closed gas circuit connected to a chemiluminescent nitric oxide analyser, (Dasibi Environmental Corp, Glendale, Calif, USA) for NO and Spacelabs Capnograph Model 90513-30 (Redmond, Wash, USA) for $\mathrm{CO}_{2}$. The values obtained are therefore an average of mixed expired gas concentrations of one or two expirations.

\section{Protocol}

\section{Part one}

All patients and attendants provided an expired NO sample prior to compression, the patients then underwent a standard 90-minute HBOT session at 2.4 atmospheres absolute (ATA), breathing $100 \% \mathrm{O}_{2}$. These sessions involve a five to ten minute compression phase breathing air, 90 minutes breathing $100 \%$ oxygen at 2.4 ATA by demand valve mask or hood, and a further 20 minutes slow decompression while continuing to breathe oxygen. The total time in the chamber for each session is therefore approximately two hours. During this period they were accompanied by a trained hyperbaric chamber nursing attendant who breathed air during the compression and 2.4 ATA periods, before starting $100 \%$ oxygen for the 20 -minute decompression phase. This is a standard operating procedure to reduce the risk of decompression illness for the attendant. For our experimental protocol, the attendants supplied a further sample of expired gas at 2.4 ATA before starting their oxygen breathing period.

Immediately on exiting the hyperbaric chamber, a further exhaled NO sample was taken from patients and staff.

\section{Part two}

A separate section studied normal subjects breathing $40 \%$ oxygen for 90 minutes via a face mask at 1 ATA. Exhaled NO samples were collected every 15 minutes.

\section{Part three}

A549 cells, an immortalised cell line derived from a lung epithelial cell carcinoma, were used as a model of airway epithelium. These cells have been demonstrated to be able to express iNOS and to be able to generate nitrite [29]. Four plates of $2-4 \times 10^{6}$ A549 cells were incubated in F12-K media with $10 \%$ foetal calf serum (FCS) and exposed to the following conditions for $90 \mathrm{~min}$ : (a) room temperature and ambient air (plate A); (b) 100\% oxygen at normal pressure (plate B); (c) air at 2.4 ATA pressure (plate C); and (d) $100 \%$ oxygen at 2.4 ATA (plate D). Interferon gamma is known to stimulate A549 cells to increase NO production [30]. Under each of the conditions, A549 cells were therefore cultured in media with 0,10 , and $20 \mathrm{ng} / \mathrm{mL}$ recombinant human interferon gamma (hIFN $\gamma$, Serotec Ltd, $\mathrm{UK})$. Nitrite/nitrate (NOx) was measured by using a fluorescent method [31]. Samples were mixed with NADPH, FAD (Sigma, Sydney, Australia), and nitrate reductase with a final concentration of $50 \mu \mathrm{M}, 5 \mu \mathrm{M}$, and $50 \mathrm{IU} / \mathrm{L}$, respectively, and incubated in $37^{\circ} \mathrm{C}$ for $1 \mathrm{~h}$, which allows nitrate to be converted to nitrite. Nitrite was conjugated with $0.05 \mathrm{mg} / \mathrm{mL}$ 2,3-diaminonaphthalene (DAN) in $0.62 \mathrm{M} \mathrm{HCL}$ to allow quantification by fluorescence. The reaction was terminated with $2.8 \mathrm{M} \mathrm{NaOH}$. The resultant fluorescence was immediately read on a CytoFluro Series 4000, Multiwell Plate Reader (Perseptive Biosystems, Mass, USA) at excitation 360/40, emission 395/25, gain 50, limit of detection $2 \mu \mathrm{mol} / \mathrm{L}$, mean (SD) intra-assay coefficient of variation 3.11(3.42)\%. Data are expressed as \% change from baseline.

\section{Analysis}

Data are presented as mean $\pm \mathrm{SE}$. The results were analysed using changes in $\mathrm{NO}(\mathrm{ppb})$ and $\mathrm{CO}_{2}(\mathrm{mmHg})$, after the $\mathrm{NO}$ values were log transformed to the normal distribution [13]. Student's $t$ test was used to calculate $P$-values, which were considered significant if $P<.05$. 
TABLE 1: Subject characteristics.

\begin{tabular}{l|cc}
\hline & $\begin{array}{l}\text { Patients } \\
\text { (male/female) }\end{array}$ & $\begin{array}{l}\text { Normal controls } \\
\text { (male/female) }\end{array}$ \\
\hline Smoker & $1 / 0$ & $0 / 0$ \\
Ex-smoker & $0 / 0$ & $2 / 0$ \\
Nonsmoker & $9 / 5$ & $6 / 8$ \\
Asthma & $1 / 0$ & $0 / 0$ \\
NSAID & $2 / 0$ & $0 / 0$ \\
Steroids & $2 / 1$ & $0 / 0$ \\
Foot ulcers & 6 & 0 \\
Osteoradionecrosis & 7 & 0 \\
Dental caries & 1 & 0 \\
Radiation cystitis & 1 & 0 \\
Lumbar cord oedema & 1 & 0 \\
\hline Total & $10 / 5$ & $8 / 8$ \\
\hline
\end{tabular}

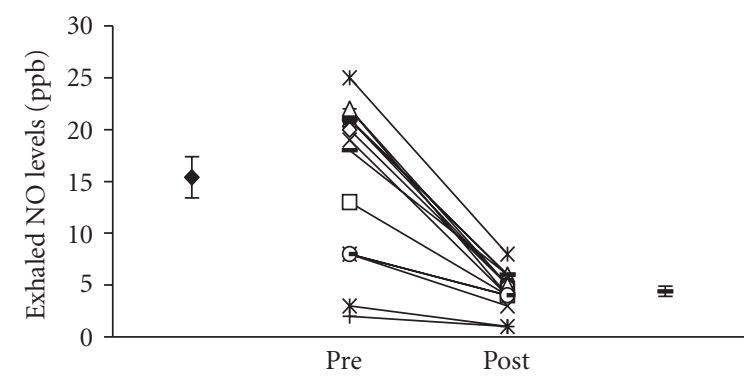

FIGURE 1: Exhaled nitric oxide levels in 15 patients undergoing HBOT immediately before and after treatment. There was a significant fall in these patients (mean $\pm \mathrm{SE}$, before $15.4 \pm 2.0 \mathrm{ppb}$, afterwards $4.4 \pm 0.5 \mathrm{ppb}, P<.001$ ).

\section{RESULTS}

\section{Part one}

In total, 16 attendants and 15 patients were recruited. Of the patients, 12 were not on current glucocorticosteroid therapy and 10 were not current steroid or NSAID users (Table 1). One attendant omitted to collect a breath sample in the chamber and other two samples collected in the chamber were lost due to overexpansion and ultimate failure of the gas collection bag during decompression. Mean (SD) coefficient of variation of interbag exhaled NO levels was 6.36(1.17)\%.

The initial mean eNO level in patients was significantly higher than both that in attendants $(15.4 \pm 2.0 \mathrm{ppb}$ vs $7.6 \pm$ $1.1 \mathrm{ppb}, P<.05)$ and the normal subjects in Part $2(5.3 \pm$ $1.0 \mathrm{ppb}, P<.01)$. No difference in the initial exhaled NO level was found between the attendants and normal subjects at 1 ATA $(7.6 \pm 1.1 \mathrm{ppb}$ vs $5.3 \pm 1.0 \mathrm{ppb}$, resp, $P=.14)$.

\section{Patients}

eNO significantly decreased after HBOT (Figure 1, $15.4 \pm 2.0$ vs $4.4 \pm 0.5 \mathrm{ppb}, P<.001, n=15)$. This effect was present in both the subgroup not on glucocorticosteroids $(15.2 \pm 2.3$

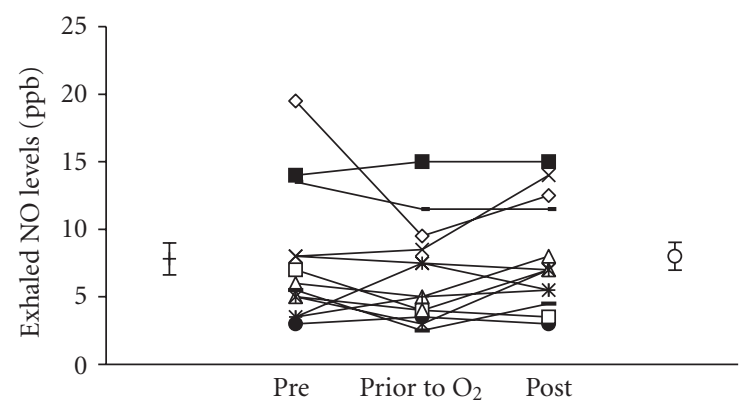

FIgURE 2: Exhaled nitric oxide levels in 16 normal staff members who were exposed to the hyperbaric environment but did not use oxygen until immediately prior to decompression. There were no significant changes between the samples.

vs $4.3 \pm 0.6 \mathrm{ppb}, P<.001, n=12)$ and in the subgroup on neither glucocorticosteroids nor NSAIDs $(16.1 \pm 2.5$ vs $4.4 \pm 0.6 \mathrm{ppb}, P<.001, n=10)$. Exhaled $\mathrm{CO}_{2}$ showed a small but significant increase following HBOT in the patient group $(25.5 \mathrm{mmHg} \pm 1.0$ vs $27.3 \mathrm{mmHg} \pm 0.9, P<.05)$.

\section{Attendants in the hyperbaric chamber}

The mean exhaled NO level before hyperbaric exposure was $7.6 \pm 1.1 \mathrm{ppb}$ and the mean level was $7.9 \pm 0.9 \mathrm{ppb}$ (Figure 2, $P=.46, n=16$ ) afterwards.

\section{Part two}

\section{Normal subjects breathing $40 \%$ oxygen at 1 ATA}

Mean exhaled NO levels in this normal group of subjects were $5.3 \pm 1.0 \mathrm{ppb}$ before and $4.6 \pm 1.1$ after 90 -minute $40 \%$ oxygen inhalation $(P=.22, n=8)$, with no significant change in exhaled NO levels at any of the 15-minute intervals.

\section{Part three}

There was a significant decrease in NOx release into the cell culture media after exposure to 100\% oxygen for 90 minutes in the A549 cells incubated in media alone (32.49\% change from baseline vs $9.38 \%, P<.01)$ and media with $20 \mathrm{ng} / \mathrm{mL}$ hIFN $\gamma(33.58 \%$ vs $9.25 \%, P<.05)$. The hyperbaric environment alone did not cause significant changes $(32.49 \%$ vs $22.80 \%, P=.32$ in media only, and $33.58 \%$ vs $20.64 \%$, $P=.29$ in media with $20 \mathrm{ng} / \mathrm{mL}$ hIFN $\gamma$ ).

\section{DISCUSSION}

In this study, eNO levels of patients were significantly decreased after HBOT. In normal subjects eNO did not decrease significantly after either a short exposure to $100 \%$ oxygen during decompression, or $40 \%$ oxygen for 90 minutes in normal subjects. The decrease in eNO seen in the HBOT patient group has been observed in studies using oxygen at 1 ATA. For example, Tsuchiya demonstrated inhalation of 
$100 \%$ oxygen for 50 minutes reduced exhaled NO levels while inhalation of $40 \%$ oxygen in a second group of mechanically ventilated human subjects undergoing surgery did not [21]. It is possible, however, that endogenous NO might be affected by anaesthetic agents, surgery, the increased airway pressure during mechanical ventilation, and these individuals may not show the same response as spontaneously breathing individuals. It is worth noting that both our study and that of Tsuchiya showed that $40 \%$ oxygen inhalation did not change eNO levels significantly [21]. The $40 \%$ oxygen inhalation was chosen as it allowed a conventional mask to be used, but it would have been a more accurate comparison of the equivalent 2.4 ATA exposure if $50.4 \%$ oxygen had been used.

In Part 1 of this study, no significant changes in eNO levels were observed in normal subjects after breathing hyperbaric air at 2.4 ATA for 90 minutes. This exposure is equivalent to breathing $50.4 \%$ oxygen at 1 ATA (the inspired pO2 is approximately $361 \mathrm{mmHg}$ in each case). Compared with the hyperbaric oxygen at the same pressure inhaled by the patients, it could be concluded that pressure is not the main factor altering the eNO levels in this study, although these normal subjects had a lower baseline eNO.

The increase in exhaled $\mathrm{CO}_{2}$ in the patients is presumably due to either stimulation of NADPH turnover through the pentose cycle or, more likely, suppression of their hypoxic ventilatory drive [32-34].

The attendants received less hyperbaric oxygen exposure than the patients and we acknowledge this may bias the result towards no change in these individuals. In addition, this group was younger and generally more physically fit. The lack of inflammatory diseases in both control groups probably accounts for the difference in baseline eNO between them and the patients. Half of the patients had osteoradionecrosis of the head and neck, initial mean exhaled NO $15.0 \pm 2.88 \mathrm{ppb}$, which may be associated with inflammation of the upper airway. Those without osteoradionecrosis, however, had a similar baseline exhaled NO. The reason for this is unclear but may be related to inflammation associated with their underlying condition with foot ulcers being the most common indication for HBOT. These conditions were associated with an elevated eNO above our normal range [35]. Although this was a prospective study, patients were recruited at various times during their HBOT, which may have influenced the baseline exhaled NO values. It was hypothesised that the elevated baseline exhaled NO in the patients was related to the induction of iNOS. Inducible NOS is generally not expressed unless the cells have been activated by inflammatory cytokines [7-9, 36, 37].

Inhibition of iNOS in patients by HBOT may account for the decrease of eNO levels. Recent studies have demonstrated that oxidative stress also prevented iNOS induction in intestinal epithelial cells $[38,39]$. Yuan et al showed that hyperbaric oxygen (HBO) suppressed iNOS expression in rabbit chondrocytes, and Pedoto et al reported that HBO decreased exhaled NO generation, plasma nitrite/nitrate concentration, and iNOS expression in the rat lung $[26,38,40]$. Absent or low levels of iNOS in normal subjects could explain why eNO levels did not change after oxygen inhalation.
Changes in production of ROS or inhibition of iNOS expression would be two possible reasons for the decrease in eNO after inhalation of high concentrations of oxygen for a long period although no study has addressed the effect of short exposure to HBOT in terms of oxidative status [41]. ROS generally increase inflammation, which would be expected to increase iNOS expression. It is possible, however, that ROS could react with NO, and convert it to other NOx species. This seems unlikely as the in vitro studies showed a decline in $\mathrm{NOx}$ with $\mathrm{O}_{2}$ exposure.

It has been reported that a combination of interferon gamma and interleukin 4 stimulates and maintains iNOS expression in human airway epithelium [42]. This study showed that NOx released from the A549 cell line incubated in media alone or with $20 \mathrm{ng} / \mathrm{mL}$ human interferon gamma significantly decreased after exposure to $100 \%$ oxygen, which occurred in the absence of HBO. This suggests that inhibition of iNOS may be the mechanism of the reduction in eNO seen in patients. It has been demonstrated that iNOS is expressed under resting conditions in the A549 cell line, which could explain the decrease in NOx release after 100\% oxygen exposure in the A549 cell line incubated in media only [29].

In conclusion, our results suggest that inhibition of iNOS may be the mechanism of HBOT-induced reduction in eNO. This might have beneficial effects on inflammation, a question which could to be further investigated by measurement of iNOS expression in a randomized controlled study in response to hyperoxia.

\section{ACKNOWLEDGMENT}

The participation of patients and Hyperbaric Medicine Unit staff in the research is gratefully acknowledged.

\section{REFERENCES}

[1] Kharitonov SA, Gonio F, Kelly C, Meah S, Barnes PJ. Reproducibility of exhaled nitric oxide measurements in healthy and asthmatic adults and children. European Respiratory Journal. 2003;21(3):433-438.

[2] Yates DH. Role of exhaled nitric oxide in asthma. Immunology and Cell Biology. 2001;79(2):178-190.

[3] Dukelow AM, Weicker S, Karachi TA, et al. Effects of nebulized diethylenetetraamine-NONOate in a mouse model of acute pseudomonas aeruginosa pneumonia. Chest. 2002;122(6):2127-2136.

[4] Hucke C, MacKenzie CR, Adjogble KDZ, Takikawa O, Dāubener W. Nitric oxide-mediated regulation of gamma interferon-induced bacteriostasis: inhibition and degradation of human indoleamine 2,3-dioxygenase. Infection and Immunity. 2004;72(5):2723-2730.

[5] Deynin A, Massaro AF, Kobzik L, De Sanctis GT, Drazen JM. Molecular and cellular sources of exhaled nitric oxide. In: Marczin N, Kharitonov SA, Yacoub MH, Barnes PJ, eds. Disease Markers in Exhaled Breath. Chapter 3. New York, NY: Marcel Dekker; 2003:73-89.

[6] Asano K, Chee CBE, Gaston B, et al. Constitutive and inducible nitric oxide synthase gene expression, regulation, and activity in human lung epithelial cells. Proceedings of the $\mathrm{Na}$ tional Academy of Sciences of the United States of America. 1994;91(21):10089-10093. 
[7] Andrew PJ, Mayer B. Enzymatic function of nitric oxide synthases. Cardiovascular Research. 1999;43(3):521-531.

[8] Hecker M, Cattaruzza M, Wagner AH. Regulation of inducible nitric oxide synthase gene expression in vascular smooth muscle cells. General Pharmacology. 1999;32(1):9-16.

[9] Albrecht EWJA, Stegeman CA, Heeringa P, Henning RH, van Goor H. Protective role of endothelial nitric oxide synthase. Journal of Pathology. 2003;199(1):8-17.

[10] Dupuy PM, Frostell CG. Bronchial effects of nitric oxide. In: Zapol WM, Bloch KD, eds. Nitric Oxide and the Lung. Chapter 15. New York, NY: Mercel Dekker; 1997:285-312.

[11] Karupiah G, Xie Q-W, Buller RML, Nathan C, Duarte C, MacMicking JD. Inhibition of viral replication by interferon$\gamma$-induced nitric oxide synthase. Science. 1993;261(5127): 1445-1448.

[12] Kharitonov SA, Yates D, Robbins RA, Logan-Sinclair R, Shinebourne EA, Barnes PJ. Increased nitric oxide in exhaled air of asthmatic patients. Lancet. 1994;343(8890):133-135.

[13] Yates DH, Kharitonov SA, Robbins RA, Thomas PS, Barnes PJ. Effect of a nitric oxide synthase inhibitor and a glucocorticosteroid on exhaled nitric oxide. American Journal of Respiratory and Critical Care Medicine. 1995;152(3):892-896.

[14] Gerschman R, Gilbert DL, Nye SW, Dwyer P, Fenn WO. Oxygen poisoning and $\mathrm{x}$-irradiation: a mechanism in common. Science. 1954;119(3097):623-626.

[15] Jamieson D, Chance B, Cadenas E, Boveris A. The relation of free radical production to hyperoxia. Annual Review of Physiology. 1986;48:703-719.

[16] Couroucli XI, Welty SE, Geske RS, Moorthy B. Regulation of pulmonary and hepatic cytochrome P4501A expression in the rat by hyperoxia: implications for hyperoxic lung injury. Molecular Pharmacology. 2002;61(3):507-515.

[17] Thomson MA, Yoder BA, Winter VT, et al. Treatment of immature baboons for 28 days with early nasal continuous positive airway pressure. American Journal of Respiratory and Critical Care Medicine. 2004;169(9):1054-1062.

[18] Nozik ES, Huang Y-CT, Piantadosi CA. L-Arginine enhances injury in the isolated rabbit lung during hyperoxia. Respiration Physiology. 1995;100(1):63-74.

[19] Suzuki K, Naoki K, Kudo H, et al. Impaired hypoxic vasoconstriction in intraacinar microvasculature in hyperoxiaexposed rat lungs. American Journal of Respiratory and Critical Care Medicine. 1998;158(2):602-609.

[20] Schmetterer L, Findl O, Strenn K, et al. Role of NO in the O2 and $\mathrm{CO} 2$ responsiveness of cerebral and ocular circulation in humans. American Journal of Physiology - Regulatory Integrative and Comparative Physiology. 1997;273(6):R2005-R2012.

[21] Tsuchiya M, Tokai H, Takehara Y, et al. Interrelation between oxygen tension and nitric oxide in the respiratory system. American Journal of Respiratory and Critical Care Medicine. 2000;162(4 pt 1):1257-1261.

[22] Cooke C-LM, Davidge ST. Peroxynitrite increases iNOS through NF- $\kappa \mathrm{B}$ and decreases prostacyclin synthase in endothelial cells. American Journal of Physiology - Cell Physiology. 2002;282(2):C395-C402.

[23] Cucchiaro G, Tatum AH, Brown MC, Camporesi EM, Daucher JW, Hakim TS. Inducible nitric oxide synthase in the lung and exhaled nitric oxide after hyperoxia. American Journal of Physiology - Lung Cellular and Molecular Physiology. 1999;277(3):L636-L644.

[24] Beckman JS, Beckman TW, Chen J, Marshall PA, Freeman BA. Apparent hydroxyl radical production by peroxynitrite: im- plications for endothelial injury from nitric oxide and superoxide. Proceedings of the National Academy of Sciences of the United States of America. 1990;87(4):1620-1624.

[25] Sato T, Takeda Y, Hagioka S, Zhang S, Hirakawa M. Changes in nitric oxide production and cerebral blood flow before development of hyperbaric oxygen-induced seizures in rats. Brain Research. 2001;918(1-2):131-140.

[26] Pedoto A, Nandi J, Yang Z-J, et al. Beneficial effect of hyperbaric oxygen pretreatment on lipopolysaccharide-induced shock in rats. Clinical and Experimental Pharmacology and Physiology. 2003;30(7):482-488.

[27] Kharitonov S, Alving K, Barnes PJ. Exhaled and nasal nitric oxide measurements: recommendations. The European Respiratory Journal. 1997;10(7):1683-1693.

[28] American Thoracic Society. Recommendations for standardized procedures for the online and offline measurement of exhaled lower respiratory nitric oxide and nasal nitric oxide in adults and children-1999. American Journal of Respiratory and Critical Care Medicine. 1999;160(6):2104-2117.

[29] Wei XM, Kim HS, Kumar RK, et al. Effects of cigarette smoke on degranulation and NO production by mast cells and epithelial cells. Respiratory Research. 2005;6(1):108.

[30] Robbins RA, Barnes PJ, Springall DR, et al. Expression of inducible nitric oxide in human lung epithelial cells. Biochemical and Biophysical Research Communications. 1994;203(1):209218.

[31] Misko TP, Schilling RJ, Salvemini D, Moore WM, Currie MG. A fluorometric assay for the measurement of nitrite in biological samples. Analytical Biochemistry. 1993;214(1):11-16.

[32] Bassett DJ, Fisher AB. Glucose metabolism in rat lung during exposure to hyperbaric O2. Journal of Applied Physiology. 1979;46(5):943-949.

[33] Donina ZhA, Ivanov AS, Troshikhin GV. Compensatory reactions of the rabbit respiratory system to hypoxic stimulation in hyperbaric conditions [in Russian]. Aviakosmicheskaia i Ekologicheskaia Meditsina. 1996;30(4):34-38.

[34] Fontanari P, Badier M, Guillot Ch, et al. Changes in maximal performance of inspiratory and skeletal muscles during and after the 7.1-MPa hydra 10 record human dive. European Journal of Applied Physiology. 2000;81(4):325-328.

[35] Thomas PS, Gibson PG, Wang H, Shah S, Henry RL. The relationship of exhaled nitric oxide to airway inflammation and responsiveness in children. Journal of Asthma. 2005;42(4):291295.

[36] Morris SM Jr, Billiar TR. New insights into the regulation of inducible nitric oxide synthesis. American Journal of Physiology. 1994;266(6 pt 1):E829-E839.

[37] Meng Q-H, Springall DR, Bishop AE, et al. Lack of inducible nitric oxide synthase in bronchial epithelium: a possible mechanism of susceptibility to infection in cystic fibrosis. Journal of Pathology. 1998;184(3):323-331.

[38] Yuan L-J, Ueng SWN, Lin S-S, Yeh W-L, Yang C-Y, Lin PY. Attenuation of apoptosis and enhancement of proteoglycan synthesis in rabbit cartilage defects by hyperbaric oxygen treatment are related to the suppression of nitric oxide production. Journal of Orthopaedic Research. 2004;22(5):1126-1134.

[39] Dijkstra G, Blokzijl H, Bok L, et al. Opposite effect of oxidative stress on inducible nitric oxide synthase and haem oxygenase-1 expression in intestinal inflammation: antiinflammatory effect of carbon monoxide. Journal of Pathology. 2004;204(3):296-303. 
[40] Luongo C, Imperatore F, Cuzzocrea S, et al. Effects of hyperbaric oxygen exposure on a zymosan-induced shock model. Critical Care Medicine. 1998;26(12):1972-1976.

[41] Gerschman R, Gilbert D, Nye SW, Dwyer P, Fenn WO. Oxygen poisoning and X-irradiation: a mechanism in common. 1954. Nutrition. 2001;17(2):162.

[42] Guo FH, Uetani K, Haque SJ, et al. Interferon $\gamma$ and interleukin 4 stimulate prolonged expression of inducible nitric oxide synthase in human airway epithelium through synthesis of soluble mediators. Journal of Clinical Investigation. 1997;100(4):829838. 


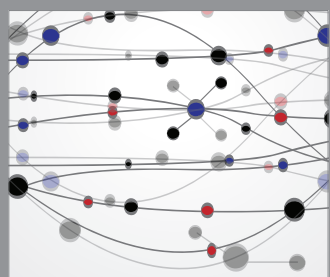

The Scientific World Journal
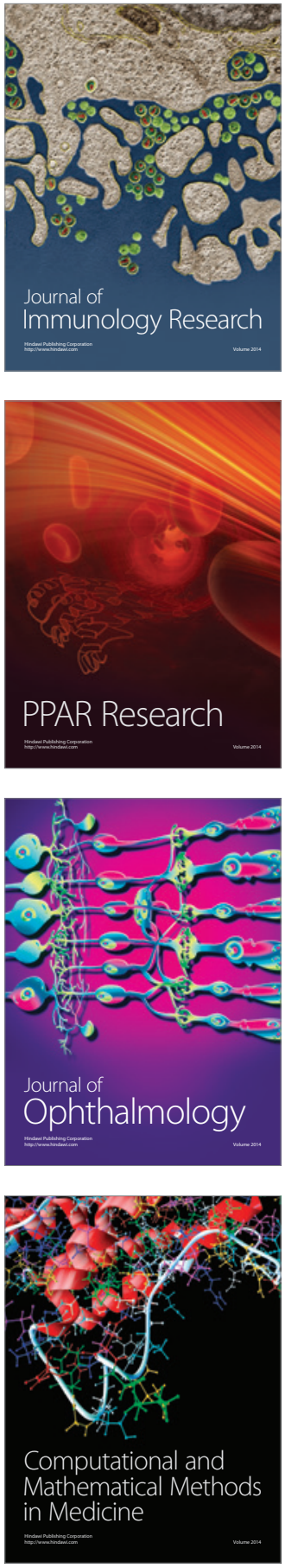

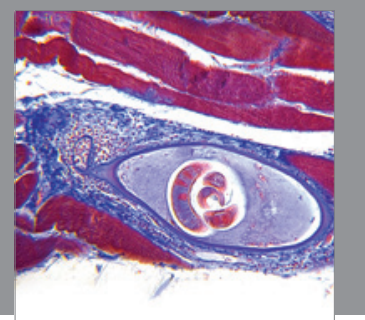

Gastroenterology

Research and Practice
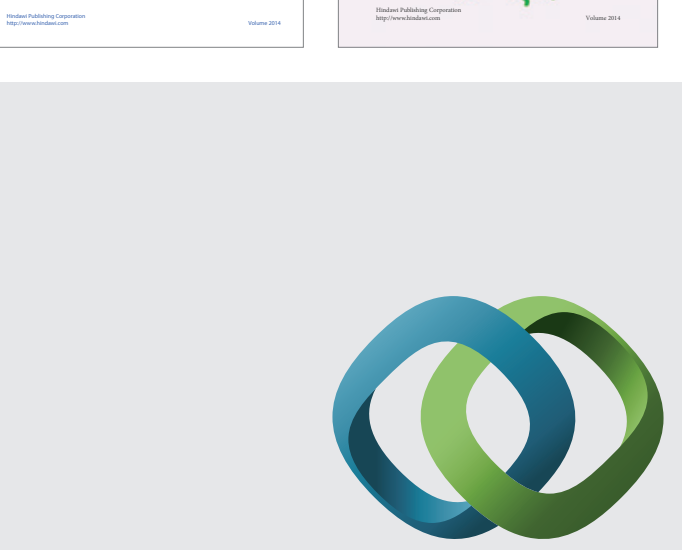

\section{Hindawi}

Submit your manuscripts at

http://www.hindawi.com
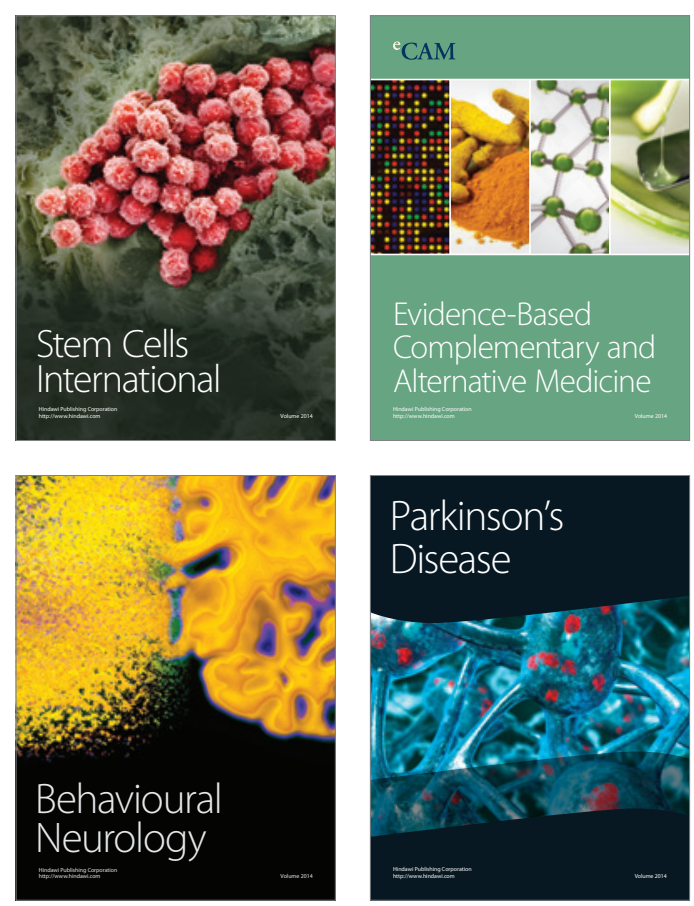

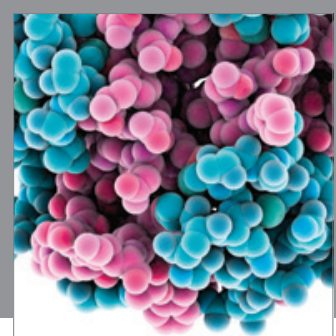

Journal of
Diabetes Research

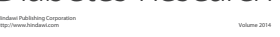

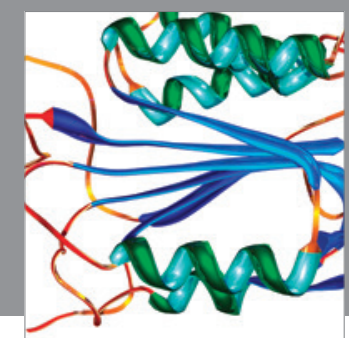

Disease Markers
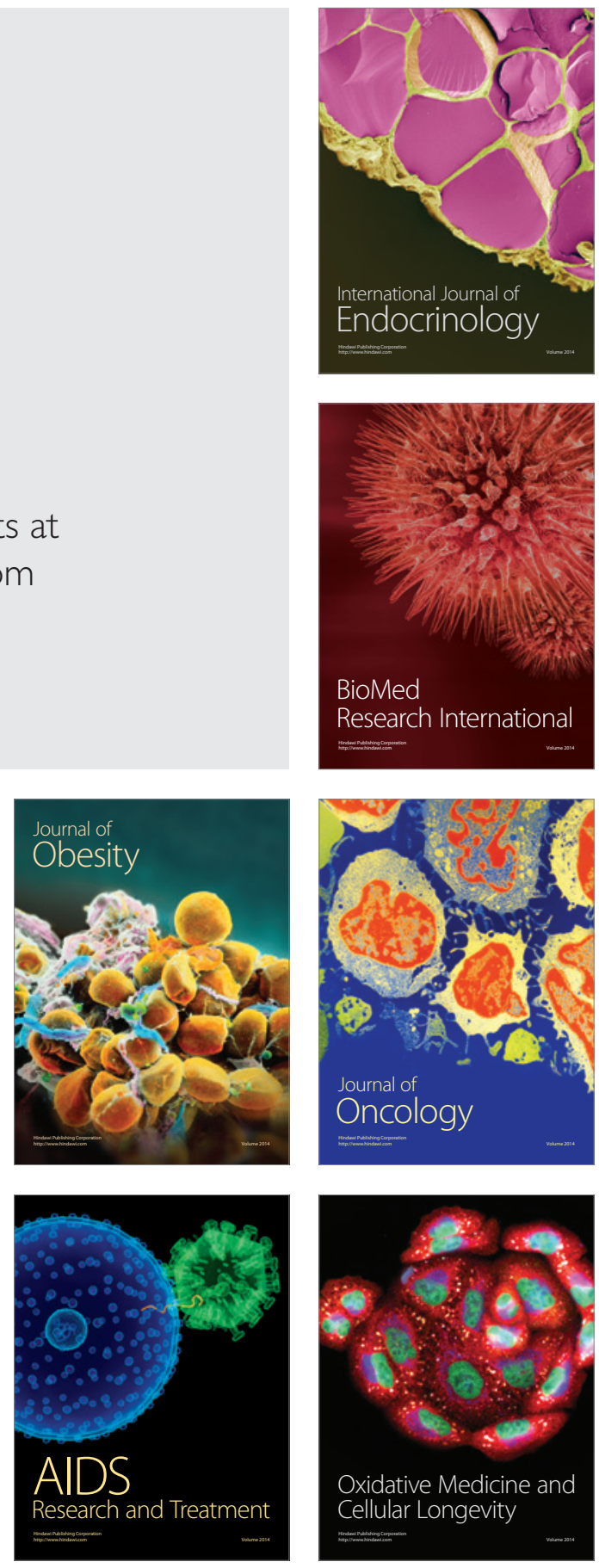